\title{
STRATEGI PENGEMBANGAN KAWASAN AGROWISATA RURUKAN
}

\author{
Ireine Gratia Palit \\ Celcius Talumingan \\ Grace A.J. Rumagit
}

\begin{abstract}
The purpose of this research is to identify the right strategy in developing Rurukan agro tourism area. The research location was conducted in two urban villages: Rurukan and Rurukan 1, East Tomohon Subdistrict, Tomohon City. This research was conducted for 3 (three) months from November 2016 to January 2017. The data used in this study are primary data and secondary data. Primary data are data taken through direct observation on site, interview with respondents who selected 10 people to fill out the research questionnaire as follows: Government (3 people), namely Lurah Rurukan, Lurah Rurukan One, and Officials of Tomohon City Tourism Office, Community Shop (2 persons) and Tour Manager (5 persons). Secondary data is data obtained from the offices of two urban villages and Tourism Office. The analytical method used SWOT Analysis. Based on the results of research and discussion, it can be concluded that the development strategy of Rurukan agro tourism area is Rapid growth strategy. This development strategy is in accordance with the position of Rurukan area that needs a progeny strategy to support growth, through several strategies that can be implemented, namely: (1) Utilizing some existing tourism object to attract investors so that it can become a growing tourism sector and interest in Tomohon; (2) utilizing the famous agro tourism with its trademark to become a cultural development area, especially in Tomohon City; (3) utilizing a good soil fertility level in the Rurukan area to be planted with fruits such as strawberries, which are highland fruit trees to be enjoyed by tourists.
\end{abstract}

Keyword: strategy, development, agrotourism, Rurukan Village, Tomohon City

\begin{abstract}
ABSTRAK
Tujuan dari penelitian ini adalah untuk mengidentifikasi strategi yang tepat dalam pengembangan kawasan agrowisata Rurukan. Lokasi penelitian dilakukan di Kelurahan Rurukan dan Rurukan 1, Kecamatan Tomohon Timur, Kota Tomohon. Penelitian ini dilakukan selama 3 (tiga) bulan yakni antara bulan November 2016 - Januari 2017. Data yang digunakan dalam penelitian ini adalah data primer dan data sekunder. Data primer adalah data yang diambil langsung dari lokasi penelitian kawasan agrowisata Rurukan melalui pengamatan langsung di lokasi, wawancara dengan pihak pemerintah, toko masyarakat, dan pengisian kuesioner. Responden yang dipilih 10 orang untuk mengisi kuesioner penelitian sebagai berikut : Pemerintah (3 orang), yaitu Lurah Rurukan, Lurah Rurukan Satu, dan Pegawai Dinas Pariwisata Kota Tomohon. Toko Masyarakat (2 orang) dan Pengelola objek wisata (5 orang). Data sekunder adalah data yang diperoleh melalui instansi terkait dengan penelitian ini, baik tabulasi maupun deskriptif. Metode analisis yang digunakan adalah analisis SWOT. Berdasarkan hasil penelitian dan pembahasan, maka dapat disimpulkan bahwa strategi pengembangan kawasan agrowisata Rurukan adalah Strategi Pertumbuhan Cepat (Rapid growth strategy). Strategi pengembangan ini sesuai dengan posisi kawasan Rurukan yang membutuhkan strategi progesif untuk mendukung pertumbuhan, melalui beberapa strategi yang dapat diimplementasikan yaitu : (1) memanfaatkan beberapa objek wisata yang sudah ada untuk menarik investor sehingga dapat menjadi sektor pariwisata yang semakin berkembang dan diminati di Kota Tomohon; (2) memanfaatkan agrowisata yang terkenal dengan ciri khasnya untuk menjadi daerah pengembangan budaya, khususnya di Kota Tomohon. (3) memanfaatkan tingkat kesuburan tanah yang baik di kawasan Rurukan untuk ditanami buah-buahan seperti strawberry yang merupakan tanaman buah dataran tinggi untuk dinikmati oleh wisatawan.
\end{abstract}

Kata Kunci: strategi, pengembangan, agrowisata, Desa Rurukan, Kota Tomohon 


\section{PENDAHULUAN}

\section{Latar Belakang}

Sektor pariwisata memiliki peluang yang cukup menjanjikan, karena selain sebagai salah satu penghasil pertumbuhan ekonomi pariwisata, sektor pariwisata juga diharapkan dapat berpeluang untuk menjadi pendorong pertumbuhan sektor pembangunan lainnya, seperti sektor perkebunan, pertanian, perdagangan, perindustrian dan lain-lain. Sementara dalam sektor pertanian, salah satu unsur yang belum tergarap secara optimal adalah agrowisata (agro tourism). Agrowisata merupakan rangkaian kegiatan wisata yang memanfaatkan potensi pertanian sebagai objek wisata, baik potensi berupa pemandangan alam kawasan pertaniannya maupun kekhasan dan keanekaragaman aktivitas produksi dan teknologi pertaniannya serta budaya masyarakat pertaniannya. Menurut Nurisjah (2001) dalam Budiarti (2013), agrowisata atau wisata pertanian didefinisikan sebagai rangkain aktivitas perjalanan wisata yang memanfaatkan lokasi atau sektor pertanian mulai dari awal produksi hingga diperoleh poduk pertanian dalam berbagai sistem dan skala dengan tujuan memperluas pengetahuan, pemahaman, pengalaman, dan rekreasi di bidang pertanian.

Pengembangan aktivitas agrowisata secara langsung dan tidak langsung akan meningkatkan persepsi positif petani serta masyarakat akan arti pentingnya pelestarian sumber daya lahan pertanian. Selain itu menurut Subowo (2002) dalam Budiarti (2013), pengembangan agrowisata dapat melestarikan sumber daya, melestarikan kearifan dan teknologi lokal, dan meningkatkan pendapatan petani atau masyarakat di sekitar agrowisata. Pengembangan agowisata akan menciptakan lapangan pekerjaan dan meningkatkan pendapatan serta meningkatkan kesejahteraan petani. Beberapa dampak positif pengembangan agrowisata antara lain meningkatkan nilai jual komoditi pertanian yang dihasilkan dan berkembangnya sumber-sumber pendapatan lainnya yang dapat dinikmati oleh masyarakat setempat seperti penyewaan homestay dan sarana rekreasi lainnya yaitu kantin, penjualan cindera mata, dan lain-lain. Selain itu, agrowisata merupakan salah satu wahana yang efektif dalam rangka promosi produk-produk pertanian dan budaya Nusantara. Hal tersebut karena selain dapat menikmati hasil pertanian secara langsung dari sumbernya, para pengunjung akan terkesan dengan sensasi wisata alam yang unik dan segar yang akan terbawa hingga mereka kembali ke tempat asalnya bahkan mereka akan bercerita kepada keluarga serta handai tolannya.

Sulawesi Utara merupakan daerah yang memiliki potensi di bidang pariwisata dan telah dikunjungi oleh banyak wisatawan baik dalam negeri maupun luar negeri. Yang menjadi salah satu daya tariknya bagi wisatawan untuk berkunjung adalah keindahan alamnya. Salah satu daerah yang memiliki keindahan alam di Sulawesi Utara adalah Kota Tomohon, khususnya Kelurahan Rurukan dan Rurukan Satu yang cocok dijadikan sebagai daerah kawasan Agrowisata. Daerah ini berada di ketinggian sekitar 700 meter dari permukaan air laut, dengan topografi yang berbukit-bukit, memiliki tanah yang subur serta iklim yang sejuk karena terletak di bawah kaki Gunung Mahawu. Kawasan Rurukan merupakan daerah sentra produksi hortikultura yaitu sayuran dan buah-buahan, seperti wortel, labu siam, buncis, bawang daun, pokcai, kubis, petsai, bunga kol, stroberi, dan lain-lain. Selain sebagai penghasil sayuran dan buah-buahan, kawasan Rurukan yang berada di daerah dataran tinggi dan memiliki keadaan topografi yang berbukitbukit, sudah sejak dahulu merupakan daerah tujuan wisata karena udaranya yang sejuk dan pemandangan yang indah. Perkembangan wisata di Rurukan sudah mulai berkembang dari tahun ke tahun, dengan munculnya objekobjek wisata yang ada di Rurukan. Objek wisata yang pertama di Rurukan adalah Puncak Temboan yang sudah ada sejak Tahun 80-an. Objek wisata selanjutnya adalah Puncak Rurukan yang mulai dibangun pada Tahun 2015 dan pembangunannya masih berlangsung sampai sekarang. Dan yang terakhir adalah objek wisata Sparta Stable Rururkan yang dibuka pada Tahun 2016. Sebelum ada objek wisata yang baru yaitu Puncak Rurukan dan Sparta Stable Rurukan, menurut masyarakat setempat bahwa jumlah pengunjung yang datang berkunjung hanya sedikit. Tetapi dengan semakin berkembangnya wisata di Rurukan dengan adanya Puncak Rurukan dan Sparta Stable Rurukan tentunya jumlah 
pengunjung yang datang semakin banyak, terutama saat hari libur penngunjung yang datang akan semakin banyak dan sering kali membuat jalanan menjadi macet. Dari data Dinas Pariwisata Kota Tomohon, pada Tahun 2016 tercatat jumlah kunjungan wisatawan pada Triwulan I berjumlah 22,205 orang, Triwulan II berjumlah 15,000 orang, Triwulan III berjumlah 23,017 orang, dan pada Triwulan IV berjumlah 17,232 orang. Dari data tersebut dapat disimpulkan jumlah wisatawan yang berkunjung ke kawasan Agrowisata Rurukan pada Triwulan II mengalami penurunan sebesar 7,205 orang jika dibandingkan pada Triwulan I. Kemudian mengalami peningkatan sebesar 8,017 orang pada Triwulan III. Akan tetapi pada Triwulan IV mengalami penurunan kembali sebesar 5,785 orang. (Sumber: Dinas Pariwisata Kota Tomohon Tahun 2016)

Jika hal tersebut tetap dibiarkan tanpa adanya penanganan yang tepat, maka pada tahun-tahun berikutnya jumlah kunjungan wisatawan diperkirakan akan terus mengalami penurunan. Oleh karena itu diperlukan strategi pengembangan kawasan Agrowisata Rurukan agar dapat meningkatkan jumlah kunjungan wisatawan baik wisatawan domestik dan mancanegara. Sehingga potensi yang ada kawasan Agrowisata Rurukan dapat dikembangkan semaksimal mungkin dan dapat mendatangkan keuntungan bagi pemerintah, investor, maupun masyarakat, sementara wisatawan dapat memperoleh kepuasan dengan melihat potensi agrowisata yang ada di kawasan Rurukan.

\section{Rumusan Masalah}

Berdasarkan latar belakang, maka yang menjadi permasalahan adalah bagaimana mengidentifikasi strategi yang dapat digunakan dalam pengembangan kawasan agrowisata Rurukan.

\section{Tujuan dan Manfaat Penelitian}

Tujuan dari penelitian ini adalah untuk mengidentifikasi strategi yang tepat dalam pengembangan kawasan agrowisata Rurukan. Penelitian ini diharapkan dapat bermanfaat untuk pengembangan potensi pariwisata, khususnya di kawasan agrowisata Rurukan.

\section{METODOLOGI PENELITIAN}

\section{Lokasi Dan Waktu Penelitian}

Lokasi penelitian dilakukan di Kelurahan Rurukan dan Rurukan 1, Kecamatan Tomohon Timur, Kota Tomohon. Penelitian ini dilakukan selama 3 (tiga) bulan yakni antara bulan November 2016 - Januari 2017. Lokasi penelitian ditentukan dengan pertimbangan bahwa kawasan tersebut memiliki potensi dan daya tarik wisata yang apabila dikembangkan dapat menjadi destinasi wisata di Kota Tomohon.

\section{Metode Pengumpulan Data}

Data yang digunakan dalam penelitian ini adalah data primer dan data sekunder. Data primer adalah data yang diambil langsung dari lokasi penelitian kawasan agrowisata Rurukan melalui pengamatan langsung di lokasi, wawancara dengan pihak pemerintah, toko masyarakat, dan pengisian kuesioer. Pengisian kuesioer untuk tujuan analisis strategi pengembangan kawasan agrowisata Rurukan dengan memilih responden yang memiliki kontribusi besar terhadap perumusan dan pelaksanaan strategi di kawasan agrowisata Rurukan. Responden yang dipilih 10 orang untuk mengisi kuesioner penelitian sebagai berikut :

a. Pemerintah ( 3 orang), yaitu Lurah Rurukan, Lurah Rurukan Satu, dan Pegawai Dinas Pariwisata Kota Tomohon.

b. Toko Masyarakat ( 2 orang)

c. Pengelolah objek wisata ( 5 orang)

Data sekunder adalah data yang diperoleh melalui instansi terkait dengan penelitian ini, baik tabulasi maupun deskriptif. Adapun data yang di maksud adalah : jumlah penduduk Kelurahan Rurukan dan Rurukan Satu, objek wisata, jumlah kunjungan wisatawan.

Metode pengumpulan data yang digunakan dalam penelitian ini adalah :

1. Metode Wawancara

Metode ini dilakukan dengan cara melakukan wawancara dan diskusi langsung kepada pemerintah setempat, tokoh masyarakat, dan instasi terkait.

\section{Metode Observasi}

Merupakan survei langsung ke lapangan melalui kegiatan pengamatan, penelitian, dan 
pengambilan data atau informasi terhadap aspek-aspek yang berkaitan langsung maupun tidak langsung terhadap pengembangan kawasan agrowisata.

\section{Konsep Pengukuran Variabel}

Adapun variabel dari penelitian ini yaitu

1. Mengidentifikasi indikator-indikator Kekuatan (Strengths) yang terdapat di kawasan agrowisata Rurukan.

2. Mengidentifikasi indikator--indikator Kelemahan (Weakness) yang terdapat di kawasan agrowisata Rurukan.

3. Mengidentifikasi indikator-indikator Peluang (Opportunities) yang terdapat di kawasan agrowisata Rurukan.

4. Mengidentifikasi indikator-indikator Ancaman (Threats) yang terdapat di kawasan agrowisata Rurukan.

\section{Metode Analisis Data}

Metode analisis yang digunakan dalam mengidentifikasi strategi pengembangan kawasan agrowisata Rurukan adalah dengan menggunakan Analisis SWOT. Menurut Rangkuti (2015), Analisis SWOT yaitu membandingkan antara faktor eksternal peluang (opportunities) dan ancaman (threats) dengan faktor internal kekuatan (strengths), dan kelemahan (weaknesses). Dalam melakukan pertimbangan profesional pada analisis faktor strategis internal dan eksternal memiliki pembatas. Pembobotan pada lingkungan internal tingkat kepentingannya didasarkan pada besarnya pengaruh faktor strategis terhadap posisi strategisnya, sedangkan pada lingkungan eksternal didasarkan pada kemungkinan memberikan dampak terhadap faktor strategisnya (Rangkuti, 2015). Jumlah bobot pada masing - masing lingkungan internal dan eksternal harus berjumlah $=1(\mathrm{satu})$. Skor total internal total bobot kekuatan + total bobot kelemahan $=1$. Skor total ekstemal total bobot peluang + total bobot ancaman $=1$

Sedangkan nilai bobot menurut Freddy Rangkuti (2015) berdasarkan ketentuan sebagai berikut: "Skala 1.0 (sangat penting) sampai dengan 0,0 (tidak penting)". Besarnya rata - rata nilai bobot tergantung pada jumlah faktor strategisnya (5-10 faktor strategis) yang dipakai. Nilai rating berdasarkan besarnya pengaruh faktor strategis terhadap kondisi dirinya
(Rangkuti, 2015) dengan ketentuan sebagai berikut:

1. Skala mulai dari 4 (sangat kuat), 3 (kuat), 2 (kurang kuat) sampai dengan 1 (tidak kuat / lemah).

2. Variabel yang bersifat positif (variabel kekuatan dan peluang) diberi nilai dari 1 sampai dengan 4 dengan membandingkan dengan rata - rata pesaing utama / kondisi wilayah didaerah lain. Sedangkan variable yang bersifat negative kebalikannya, jika kelemahan dan ancaman besar sekali (dibanding dengan rata-rata pesaing sejenis) nilainya adalah 1 , sedangkan ancaman kecil di bawah rata - rata pesaingnya nilainya adalah 4. Matrik SWOT adalah matrik yang mengintraksikan faktor strategis internal dan eksternal. Matrik ini dapat menggambarkan secara jelas bagaimana peluang dan ancaman (eksternal) yang dihadapi dapat disesuaikan dengan kekuatan dan kelemahan (internal) yang dimiliki. Hasil dari interaksi faktor strategis internal dengan eksternal menghasilkan alternative-alternative strategi. Matrik SWOT menggambarkan berbagai altemative strategi yang dilakukan didasarkan hasil analisis SWOT. Strategi SO adalah strategi yang digunakan dengan memanfaatkan/ mengoptimalkan kekuatan yang dimilikinya untuk memanfaatkan sebagai peluang yang ada. Sedang strategi WO adalah strategi yang digunakan seoptimal mungkin untuk meminimalisir kelemahan. Strategi ST adalah strategi yang digunakan dengan memanfaatkan / mengoptimalkan kekuatan untuk mengurangi berbagai ancaman. Strategi WT adalah strategi kelemahan dalam untuk mengurangi kelemahan dalam rangka yang digunakan meminimalisir / menghindari ancaman.

a. Analisis faktor- faktor strategis internal dan ekstemal (IFAS - EFAS). Analisis faktor strategi internal dan ekstemal adalah pengolahan faktor-faktor strategis pada lingkungan intemal dan ekstemal dengan memberikan pembobotan dan rating pada setiap faktor srtategis. Menganalisis Iingkungan internal (IFAS) untuk mengetahui berbagai kemungkinan kekuatan dan kelemahan. Masalah strategis yang akan dimonitor harus ditentukan karena masalah mungkin dapatmempengaruhi pariwisata 
dimasa yang akan datang. Menganalisis lingkungan eksternal (EFAS) untuk mengetahui berbagai kemungkinan peluang dan ancaman. Masalah strategis yang akan dimonitor harus ditentukan karena masalah ini mungkin dapat mempengaruhi pariwisata dimasa yang akan datang.

1) Kolom 1 : Disusun faktor-faktor yang menjadi kekuatan, kelemahan, peluang dan ancaman perusahaan.

2) Kolom 2 : Memberikan bobot masingmasing faktor dengan skala mulai dari 1,0 (sangat penting) sampai 0,0 (tidak penting). Pemberian bobot setiap variabel menunjukan pengaruh masing-masing variabel terhadap faktor strategi perusahaan. Menurut Kinnear (1991) dalam Mappigau dan Esso (2011), bobot setiap variabel diperoleh dengan menentukan nilai setiap variabel terhadap jumlah nilai keseluruhan variabel dengan menggunakan rumus :

$\alpha \mathrm{i}=\frac{x i}{\sum_{i=1}^{n} x i}$

Dimana :

$\alpha \mathrm{i}=$ bobot variabel ke-i

$\mathrm{xi}=$ nilai variabel ke-i

$\mathrm{i}=1,2,3$,

$\mathrm{n}=$ jumlah variabel

3) Kolom 3 : Hitung rating (dalam kolom 3) untuk masing-masing faktor denagan memberikan skala mulai dari 4 (outstanding) sampai dengan 1 (poor) berdasarkan pengaruh faktor tersebut terhadap kondisi perusahaan yang bersangkutan. Pemberian nilai rating untuk faktor peluang bersifat positif (peluang yang semakin besar diberi rating +4 , tetapi jika peluangnya kecil, diberi rating +1 ). Pemberian nilai rating ancaman adalah kebalikannya. Misalnya, jika nilai ancamannya sangat besar, ratingnya adalah 1. Sebaliknya, jika nilai ancamannya sedikit ratingnya 4 . Variabel yang bersifat positif (semua variabel yang masuk kategori kekuatan) diberi nilai +1 sampai dengan +4 (sangat baik) dengan membandingkan rata industri atau dengan pesaing utama. Sedangkan variabel yang bersifat negatif kebalikanya. Contohnya jika kelemahan besar sekali dibandingkan dengan rata-rata industri yang nilainya adalah 1 , sedangkan jika kelemahan dibawah rata-rata industri, nilainya adalah 4 .
4) Pada kolom 4 : Mengalikan bobot dan rating untuk memperoleh skor pembobotan. Setelah mengetahui skor pembobotan, jumlahkan skor pembobotan (kolom 4) untuk memperoleh total skor pembobotan bagi perusahaan yang bersangkutan. Nilai total ini menunjukan bagaimana perusahaan tertentu beraksi terhadap faktor-faktor strategis.

b. Pemetaan posisi pariwisata.

Pemetaan posisi pariwisata bertujuan untuk mengetahui posisi pariwísata dari suatu objek wisata dalam kondisi perkembangannya saat ini. Pemetaan didasarkan pada analogi sifat yang dimiliki dari faktor-faktor strategis. Kekuatan memiliki sifat positif, kelemahan bersifat negatif, begitu juga dengan peluang bersifat positif dan ancaman bersifat negativ. Diagram posisi perkembangan pariwisata memberikan gambaran keadaan perkembangan pariwisata berdasarkan kuadran-kuadran yang dihasilkan garis Vektor SW dan garis Vektor OT, setiap kuadran memiliki rumusan strategi sebagai strategi utamanya. Seperti lelah dijelaskan sebelumnya garis Vektor pada diagram posisi perkembangan pariwisata didasarkan pada logika faktor strategi internal membentuk garis horisontal dan faktor strategi ekstemal membentuk garis vertikal.

Rumusan setiap kuadran yang secara khusus untuk pariwisata dan beberapa pengertian yang melalui proses adopsi, adaptasi dari penggunaan analisis SWOT untuk perusahaan, sehingga diadaptasi sutu rumusan sebagai berikut:

1) Kuadran I : Growth (perlumbuhan)

Strategi pertumbuhan didesain untuk mencapai pertumbuhan, baik dalam penjualan, aset, proñt atau kombinasi ketiganya (Rangkuti, 2015). Pertumbuhan dalam pariwisata adalah pertumbuhan jumlah kunjungan wisatawan (frekuensi kunjungan dan asal daerah wisatawan), aset (objek dan daya tarik wisata, prasarana dan sarana pendukung), pendapatan (retribusi masuk dan jumlah yang dibelanjakan). Pertumbuhan dalam pariwisata terbagi dua, yaitu :

a. Rapid Growth Strategy (strategi pertumbuhan cepat), adalah strategi meningkatkan laju pertumbuhan kunjungan 
wisatawan dengan waktu lebih cepat (tahun ke 2 lebih besar dari tahu ke 1 dan selanjutnya), peningkatan kualitas yang menjadi faktor kekuatan untuk memaksimalkan pemanfaatkan semua peluang.

b. Stable Growth Strategy (strategi pertumbuhan stabil), adalah strategi mempertahankan pertumbuhan yang ada (kenaikan yang stabil, jangan sampai turun).

2) Kuadran Il : Stability

Stabilitas diarahkan untuk mempertahankan suatu keadaan dengan berupaya memanfaatkan peluang dan memperbaiki kelemahan. Strategi stabilitas terbagi dua, yaitu :

a. Agressive Maintenance strategy (strategi perbaikan agresi), adalah strategi konsolidasi internal dengan mengadakan perbaikanperbaikan berbagai bidang. Perbaikan faktorfaktor kelemahan untuk memaksimalkan pemanfaatan peluang.

b. Selective Maintenance strategy (strategi perbaikan pilihan), adalah strategi konsolidasi internal dengan melakukan perbaikan pada sesuatu yang menjadi kelemahan. Memaksimalkan perbaikan faktor-faktor kelemahan untuk memanfaatkan peluang.

3) Kuadran 111 : Survival (Bertahan)

a. Turn around strategy (strategi memutar balik), adalah strategi yang membalikan kecenderungan-kecenderungan negatif sekarang, yang paling umum tertuju pada pengelolaan.

b. Guirelle strategy (strategi merubah fungsi), adalah strategi merubah fungsi yang dimiliki dengan fungsi lain yang bener-benar berbeda.

4) Kuadran IV : Diversifkasi

Strategi penganekaragaman adalah strategi yang membuat keanekaragaman terhadap objek dan daya tarik wisata dan mendapatkan dana investasi dari pihak luar. Strategi penganekaragaman dibagi dua :

a. Diversifikasi concentric strategy (strategi diversiflkasi konsentrik), adalah diversiñkasi objek dan daya tarik wisata sehingga dapat meminimalisir ancaman.

b. Diversifikasi conglomera strategy (strategi diversinkasi konglomerat), adalah memasukan investor untuk mendanai diversikasi yang mempertimbangkan laba.

Alternative strategi merupakan hasil matrik analisis SWOT yang menghasilkan berupa strategi SO, WO, ST, dan WT. Alternative strategi yang dihasilkan minimal 4 (empat) strategi sebagai hasil dari analisis matrîk SWOT.

1. Strategi SO, strategi ini dibuat berdasarkan jalan pikiran memanfaatkan seluruh kekuatan untuk merebut dan memanfaatkan peluang sebesar besamya.

2. Strategi ST, strategi dalam menggunakan kekuatan yang dimiliki untuk mengatasi ancaman.

3. Strategi WO, diterapkan berdasarkan pemanfaatan peluang yang ada dengan cara meminimalkan kelemahan yang ada.

4. Strategi WT, didasarkan pada kegiatan usaha meminimalkan kelemahan yang ada serta menghindari ancaman.

\section{HASIL DAN PEMBAHASAN}

\section{Gambaran Umum Lokasi Penelitian}

Kawasan Rurukan berada pada ketinggian 1100-1300 mdl di atas permukaan air laut dan terbagi menjadi 2 Kelurahan, yaitu Kelurahan Rurukan dan Rurukan 1. Kelurahan Rurukan memiliki luas wilayah $350 \mathrm{Ha}$, dan Kelurahan Rurukan 1 memiliki luas wilayah 155,8 Ha. Kelurahan Rurukan terdiri dari 463 KK dengan jumlah penduduk mencapai 1.808 jiwa, dan Kelurahan Rurukan 1 terdiri dari 343 KK dengan jumlah penduduk mencapai 1.256 jiwa. Adapun batas wilayah Kawasan Rurukan yaitu :

a. Sebelah Utara berbatasan dengan Sebelah Selatan berbatasan dengan Kabupaten Minahasa

b. Sebelah Timur berbatasan dengan Kelurahan Weweleng

c. Sebelah Barat berbatasan dengan Kelurahan Talete Satu dan Paslaten Satu

d. Kelurahan Kumelembuai

\section{Aspek Fisik Dasar}

\section{Kondisi Geografis}

Kawasan Rurukan berada pada ketinggian 1.100-1.300 mdl di atas permukaan laut, dan memiliki keadaan lahan yang miring 
dan curam dengan kemiringan lahan berkisaran antara $45 \%$ - $75 \%$ keatas. Hal ini menunjukan bahwa pembangunan hanya bisa berlangsung pada sebagian wilayah.

\section{Kondisi Hidrologi}

Kondisi hidrologi atau keadaan air yang ada di Kawasan Rurukan dapat dilihat pada dua kondisi, yaitu air tanah dan air permukaan. Air tanah dapat dilihat dengan adanya sumur-sumur dan tempat pemandian umum yang digunakan oleh masyarakat untuk kebutuhan sehari-hari. Kemudian air permukaan dapat dilihat dengan adanya anak-anak sungai yang dipergunakan oleh masyarakat sumber pengairan bagi kegiatan pertanian. Dengan demikian potensi wilayah aliran sungai dan mata air tersebut sangat mendukung untuk kebutuhan irigasi pertanian dan sumber air bersih untuk kebutuhan penduduk.

\section{Geologi dan Jenis Tanah}

Kondisi geologi dan jenis tanah secara umum di Kawasan Rurukan tersusun atas jenis tanah ordo andisol dengan solum tanah yang tebal. Dan dengan jenis tanah ini sangat cocok dan subur untuk ditanami berbagai jenis tumbuhan sehingga memungkinkan untuk dijadikan pengembangan agrowisata.

\section{Klimatologi}

Keadaan iklim di Kawasan Rurukan secara umum beriklim tropis. Terdapat curah hujan yang signifikan sepanjang tahun, bahkan pada saat bulan kering sering memiliki banyak curah hujan dengan suhu rata-rata pertahun $21^{\circ} \mathrm{C}$. Suhu yang tidak terlalu panas dan tidak terlalu dingin ini sangat mendukung pertumbuhunan tanaman sehingga memungkinkan untuk pengembangan agrowisata.

\section{Jarak Antar Wilayah}

Jarak merupakan salah satu yang penting untuk kemajuan suatu kawasan. Kawasan Rurukan merupakan kawasaan yang berada di perbukitan, maka jarak tempuh merupakan hal yang sangat penting untuk pertimbangan, terlebih lagi masih banyak kondisi jalan yang kondisisnya masih kurang layak atau rusak untuk dilalui kendaraan. Pada umumnya jarak antar Kawasan Rurukan dengan
Pusat Kota Tomohon yaitu 5,3 km dengan waktu tempuh sekitar 15 menit dan jarak dari Kawasan Rurukan ke Kota Manado yaitu 29 km dengan waktu tempuh sekitar 60 - 75 menit.

\section{Aspek Demografi}

\section{Perkembangan Jumlah Penduduk}

Adapun Perkembangan jumlah penduduk di Kawasan Rurukan mengalami grafik pertumbuhan penduduk yang tidak statis karena pertumbuhan penduduknya dari tahun ketahun terjadi peningkatan dan penurunan.

Tabel 1. Perkembangan Jumlah Penduduk Desa Rurukan
dan Rurukan Satu menurut Kecamatan Tomohon
Timur Tahun 2011-2015

Pada Tabel 1 menunjukan bahwa dari Tahun 2011-2015 jumlah pendudukan di Rurukan mengalami fluktuasi. Hal ini dapat di lihat pada Tahun 2013 mengalami peningkatan jumlah penduduk menjadi 3.058 orang dari Tahun 2012 sebanyak 2.959, dan meningkat lagi pada Tahun 2014 menjadi 3.267. Tetapi pada Tahun 2015 menurun menjadi 2.954 dari Tahun 2014 sebanyak 3.267. Meskipun mengalami penurunan tetapi sebagian besar penduduk lebih memilih untuk tetap tinggal di Kawasan Rurukan dan bekerja sebagai petani. Dengan melihat kondisi ini mengindiksikan bahwa Kawasan Rurukan berpotensi untuk pengembangan Kawasan agrowisata.

\section{Sosial Ekonomi}

Salah satu tolak ukur dalam taraf kesejahteraan masyarakat adalah tingkat pendapatan yang tercermin dalam akivitas penduduk yang setiap hari bekerja sebagai petani. Selain tanaman holtikultura, buah strawberry menjadi salah satu budidaya andalan di Kawasan ini. Buah strawberry dapat ditemukan di kawasan Puncak Temboan. Hawa yang sejuk dan pemandangan yang indah akan sangat menarik perhatian saat memasuki kawasan ini. Di depan pintu masuk biasanya telah tersusun buah-buah strawberry yang telah di masukan didalam kemasan yang telah siap 
untuk dijual. Kondisi di Puncak Temboan yang berbukit dengan udara yang sejuk memang cocok bila ditanami dengan buah strawberry. Selain buah strawberry, tanaman holtikultura yaitu wortel, labu siam, buncis, bawang daun, pokcai, petsai, bunga kol dan sebagainya, telah membantu secara langsung perekonomian masyarakat sekitar. Menurut data yang didapat mengenai jenis pekerjaan sebagian besar penduduk yang bermukim di Kawasan Rurukan bekerja sebagai petani dan sebagian kecil yang bekerja sebagai PNS, POLRI, Pensiunan, Wiraswasta, Swasta, dll.

\section{Sosial Dan Budaya Masyarakat}

Masyarakat yang mendiami Kawasan Rurukan merupakan penduduk asli Minahasa dan menggunakan bahasa tombulu dan manado sebagai bahasa pengantar sehari-hari. Ditinjau dari aspek sosal budaya atau adat istiadat, masyarakat Rurukan masih erat atau kental dengan adat Minahasa terlebih di kawasan ini gotong-royong atau biasa di sebut mapalus masih terlihat dengan jelas di kehidupan bermasyarakat. Secara umum, hampir sebagian besar masyarakat yang tinggal di Rurukan memiliki jalinan atau ikatan kekeluargaan satu sama lain.

\section{Jalan}

\section{Aspek Prasarana}

Jalan merupakan prasarana pengangkut darat yang memegang peranan yang sangat penting dalam pertumbuhan dan perkembangan wilayah atau kawasan. Tumbuhnya pusat-pusat pelayanan baru dapat memicu karena adanya jaringan jalan. Pada wilayah penelitian, berdasarkan hasil pengamatan lapangan, ketersediaan jaringan jaringan jalan yang ada sebagian besar sudah beraspal dengan lebar \pm 5 meter. Jalan sudah mampu mendukung arus pergerakan penduduk serta kendaraan, dimana konstruksi

\section{Air Bersih}

Air merupakan kebutuhan pokok mahkluk hidup yang harus terpenuhi setiap saat. Air dibutuhkan untuk keperluan pertanian, industri dan lain-lain. Pemenuhan air bersih untuk keperluan konsumsi penduduk di Rurukan berasal dari sumur-sumur dan tempat permandian umum yang terdapat di dalam Kawasan Rurukan.

\section{Listrik}

Secara keseluruhan, kebutuhan energi listrik penduduk di Rurukan sudah dapat terlayani dengan ketersediaan jaringan listrik dengan menggunakan 220 volt serta kapasitas 450-900 watt untuk kebutuhan rumah tangga.

\section{Sarana Ekonomi}

Sarana ekonomi yang ada di Rurukan adalah kios/warung kecil sebanyak 44 unit sebagai sarana ekonomi yang dapat membantu pendanaan dalam mengembangkan potensi agrowisaata Rurukan. Sedangkan untuk melayani kebutuhan sayur-sayuran dan ikan, para pedagang akan langsung datang menjual sayur dan ikan dengan menggunakan mobil open cup dan motor.

\section{Jenis Penggunaan Lahan}

Penggunaan lahan yang ada di Rurukan adalah pemukiman, sawah, ladang/kebun, hutan.

\begin{tabular}{|c|c|c|c|c|c|c|}
\hline \multirow[t]{2}{*}{ No. } & \multirow[t]{2}{*}{ Kelurahan } & \multicolumn{5}{|c|}{ Penggunaan lahan } \\
\hline & & Pemukiman & Sawah & $\begin{array}{l}\text { Ladang/ } \\
\text { Kebun }\end{array}$ & Hutan & Lainnya \\
\hline 1. & Rurukan & 1.733 & 1.733 & 1.767 & 1.87 & 1.869 \\
\hline 2. & $\begin{array}{l}\text { Rurukan } \\
\text { Satu }\end{array}$ & 1.226 & 1.226 & 1.291 & 1.391 & 1.085 \\
\hline & Jumlah & 2.959 & 2.959 & 3.058 & 3.267 & 2.954 \\
\hline
\end{tabular}

Dari Tabel 2 menunjukan bahwa penggunaan lahan yang ada di Rurukan lebih besar digunakan untuk kegiatan pertanian seluas 278 Ha untuk Kelurahan Rurukan dan 146,8 Ha untuk Kelurahan Rurukan Satu.

\section{Aspek Potensi Daya Tarik Kawasa Agrowisata Rurukan \\ Kelurahan Rurukan dan Rurukan Satu} terkenal dengan keindahan alamnya serta agrowisatan yang menjadi objek wisatanya. Adapun beberapa objek wisata yang terkenal dan sering dikunjungi oleh wisatawan yaitu Puncak Temboan, Puncak Rurukan, dan Sparta Stable Rurukan.

\section{Puncak Temboan}

Objek wisata Puncak Temboan berada di Kelurahan Rurukan Satu, yang dikelolah oleh 
kelompok tani Gema Agape. Atraksi yang dimiliki objek wisata Puncak Temboan adalah hamparan kebun atau lahan pertanian dengan keindahan yang menakjubkan dengan hamparan kebun sayuran dan kebun strawberry yang dikembangkan oleh pengelolah dalam hal ini kelompok tani Gema Agape. Dengan pemandangan yang indah ini dapat menarik pengunjung untuk bersantai sambil menikmati pemandangan yang ada di objek wisata Puncak Temboan. Untuk menikmati keindahan ini, pengunjung tidak di perlu membayar tiket masuk, tetapi sebagai gantinya pengunjung hanya memberi berupa kerelaannya saja untuk pengembagan fasilitas yang ada di Puncak Temboan. Sarana dan prasarana yang tersedia di objek wisata Puncak Temboan adalah akses yang mudah untuk menuju lokasi Pucak Temboan, ketersediaan toilet, jaringan komunikasi, sumber listrik dan energi, serta adanya kantin. Akan tetapi banyak fasilitas yang disediakan oleh pengelolah diaggap belum bisa memberikan kenyamanan terhadapa wisatawan yang datang berkunjung. Hal ini dapat dilihat dari keadaan prasarana toilet umum yang masih kurang.

\section{Puncak Rurukan}

Objek wisata ini berada di Kelurahan Rurukan dan merupakan objek wisata yang kembangkan oleh investor. Hal ini menunjukan bahwa keindahan alam di Rurukan dapat menarik investor untuk berinvestasi dalam pengembangan wisata yang ada di Rurukan. Untuk menikmati objek wisata ini, pengunjung perlu membayar tiket masuk sebesar Rp. 10.000 per orang untuk wisatawan domestik dan $\mathrm{Rp}$. 15.000 per orang untuk wisatawan mancanegara. Untuk biaya parkir bus Rp. 7.500, mobil Rp. 5000, dan motor Rp. 3.000. Atraksi yang disediakan di objek wisata Puncak Rurukan adalah hamparan perkebunan atau lahan pertanian yang dikelolah oleh penduduk setempat yang menciptakan pemandangan yang indah. Puncak Rurukan juga menyediakan atraksi lainnya seperti adanya tarian Kabasaran dimana pengunjung dapat menikmati tariannya dan kemudian dapat mengambil foto bersama. Sarana dan prasarana yang disediakan oleh pengelolah adalah akses yang mudah untuk menuju lokasi Puncak Rurukan, lapangan parkir, kantin, pondok yang bisa disewa oleh pengunjung, ruangan yang disewakan untuk acara maupun rapat, bangku taman, toilet, audio system, serta beberapa bangunan yang masih dalam proses pengerjaan. Akan tetapi, banyaknya fasilitas yang disediakan oleh pengelolah dianggap belum bisa memberikan keyamanan terhadap wisatawan yang datang berkunjung. Hal ini dapat dilihat dari keadaan prasarana toilet yang sebagian besar tidak berfungsi, jalan masuk ke lokasi objek wisata yang masih belum memadai, serta banyaknya sisa-sisa material bangunan yang berada di objek wisata yang dapat mengganggu pengunjung.

\section{Sparta Stable Rurukan}

Objek wisata Sparta Stable merupakan objek wisata yang tergolong masih baru di Kelurahan Rurukan. Meskipun masih baru tetapi objek wisata ini telah mampu untuk menarik pengunjung. Objek wisata ini juga merupakan salah satu objek wisata yang dikembangkan oleh investor luar dan dikelolah oleh Keluarga Apow Kalele. Untuk masuk ke objek wisata ini, pengunjung hanya perlu membayar uang masuk sebesar Rp. 5000, dan bebas parkir. Atraksi yang disediakan oleh pengelolah objek wisata Sparta Stable adalah berupa pemandangan hamparan perkebunan atau lahan pertanian yang dikelolah oleh penduduk setempat, serta kandang kuda yang terdapat didalam objek wisata.

Sarana dan prasarana yang tersedia di objek wisata ini adalah akses jalan yang mudah untuk menuju lokasi objek wisata Sparta Stable, tersediaanya toilet, terdapatnya meja dan bangku sehingga pengunjung dapat bersantai, serta pengunjung dapat melihat langsung kuda yang dimiliki oleh investor yang berada di objek wisata ini dan pengunjung juga diperbolehkan untuk mengambil foto bersama dengan kuda tersebut. Akan tetapi, pengunjung tetap merasa bahwa objek wisata ini belum bisa memberikan kenyamanan. Hal ini dapat dilihat dari belum tersedianya lapangan parkir sehingga pengunjung yang datang hanya dapat memarkirkan kendaraan di dekat pintu masuk dan di pinggi-pinggir jalan. Serta belum tersedianya kantin di objek wisata ini.

\section{Aspek Kunjungan Wisatawan}

Jumlah wisatawan yang berkunjung di lokasi kawasan agrowisata sangatlah penting 
dalam usaha pengembangan objek wisata dan daya dukung objek. Oleh karena itu dibutuhkan data jumlah kunjungan wisatawan pada objek wisata tersebut sehingga dapat diprediksikan kecenderungan yang muncul, juga dampak negatif yang akan ditimbulkan terhadap objek dan daya dukungnya. Jumlah wisatawan yang melakukan kunjungan di kawasan Agrowisata Rurukan pada tahun 2016 mengalami jumlah kunjungan wisatawan yang tidak menentu sehingga sering terjadi peningkatan dan penurunan pengunjung pada setiap triwulannya. Hal itu terjadi seiring dengan berkurannya minat kunjungan masyarakat untuk mengunjungi kawasan wisata alam dan cenderung mengunjungi lokasi wisata yang bersifat modern.

\begin{tabular}{clll}
\multicolumn{4}{c}{ Tabel 3. Data Kunjungan Wisatawan Di Rurukan Tahun 2016 } \\
\hline No & Triwulan & Jumlah Pengunjung & Pertamhan Jiwa \\
1. & Triwulan I & 22,205 & - \\
2. & Triwulan II & 15,000 & $-7,205$ \\
3 & Triwulan III & 23,017 & 8,017 \\
4 & Triwulan IV & 17,232 & $-5,785$ \\
\hline & Jumlah & 77,454 & \\
\hline
\end{tabular}

Sumber: Kecamatan Tomohon Timur dalam Angka Tahun 2016

Berdasarkan Tabel 3 menunjukan jumlah wisatawan yang berkunjung ke kawasan Agrowisata Rurukan pada Triwulan I berjumlah 22,205 orang, Triwulan II berjumlah 15,000 orang, Triwulan III berjumlah 23,017 orang, dan pada Triwulan IV berjumlah 17,232 orang. Dari data diatas dapat disimpulkan jumlah wisatawan yang berkunjung di kawasan agrowisata Rurukan pada Triwulan II dan IV mengalami penurunan jika dibandingkan dengan Triwulan I dan Triwulan III. Pada Triwulan II terjadi penurunan pengunjung sebesar 7,205 orang jika dibandingkan dengan Triwulan I. Dan pada Triwulan III mengalami peningkatan pengunjung sebanyak 8,017 orang. Akan tetapi pada Triwulan IV kembali terjadi juga penurunan pengunjung sebesar 5,785 jika dibandingkan dengan Triwulan III.

\section{Analisis Strategi Pengembangan Kawasan Agrowisata}

Dalam menganalisis objek wisata dan daya tarik wisata khususnya agrowisata pada strategi pengembangan kawasan agrowisata Rurukan dapat menggunakan analisis SWOT. Maka dari itu menggunakan Faktor Internal dan Faktor Eksternal, yaitu : a. Faktor Internal

1. Kekuatan (Strengths)

a) Kawasan Rurukan memiliki tingkat kesuburan tanah yang baik yang mendukung pengembangan agrowisata

b) Terdapat beberapa objek wisata yang sering dikunjungi oleh wisatawan

c) Kondisi daerah yang strategis

d) Memiliki pemandangan yang indah yang di ciptakan dari cara pengolahan lahan oleh masyarakat sekitar yang dibuat dengan tersering

e) Agrowisata yang terkenal dengan ciri khasnya

2. Kelemahan (Weakness)

a) Sering terjadinya perubahan iklim yang tidak menentu

b) Kurangnya promosi

c) Kurangnya kesadaran dalam menjaga objek wisata

d) Belum tersedianya toko souvenir dan homestay

e) Kurangnya sumber daya manusia yang berpengalaman dalam mengelolah objek wisata

b. Faktor Eksternal

1. Peluang (Oppurtunities)

a) Peluang investasi bagi para investor untuk pengembangan sumber daya alam dibidang agrowisata.

b) Tersediaanya sumber daya manusia atau tenaga kerja.

c) Wisatawan dapat menikmati hasil perkebunan berupa buah strawberry.

d) Dapat menjadi daerah pengembangan budaya, khususnya di Kota Tomohon.

e) Sektor pariwisata yang semakin berkembang dan diminati

2. Ancaman (Threats)

a) Terdapat beberapa objek wisata disekitar kawasan agrowisata Rurukan

b) Kemungkinan rusaknya lingkungan alam akibat perusakan lingkungan pada kawasan agrowisata, sehingga dapat menyebabkan erosi tanah dan tanah longsor pada areal pertanian dan pada musim kemarau tidak dapat ditanami akibat kurangnya debit air sehingga hasil perkebunan akan semakin berkurang dan kualitasnya akan semakin menurun. 
c) Terjadinya alih fungsi lahan pertanian. Seperti lahan pertanian dialih fungsikan menjadi pembangunan pariwisata, yang dapat menyebabkan berkurangnya lahan pertanian yang produktif dan bahkan bisa habis pada masa mendatang.

\section{Analisis Faktor Internal (IFAS)}

Analisi lingkungan internal yang dilakukan yaitu terhadap faktor-faktor strategis internal yang terdiri dari kekuatan dan kelemahan dalam pengembangan kawasan agrowisata Rurukan.

\section{Tabel 4. Matriks IFAS}

\begin{tabular}{|c|c|c|c|c|}
\hline No & Kekuatan & Bobot & Rating & Skor \\
\hline 1 & $\begin{array}{l}\text { Kawasan Rurukan memiliki } \\
\text { tingkat kesuburan tanah yang } \\
\text { baik yang mendukung } \\
\text { pengembangan agrowisata. }\end{array}$ & 0.11 & 4.8 & 0.53 \\
\hline 2 & $\begin{array}{l}\text { Terdapat beberapa objek } \\
\text { wisata. }\end{array}$ & 0.10 & 4.3 & 0.43 \\
\hline 3 & Kondisi daerah yang strategis. & 0.09 & 4.0 & 0.36 \\
\hline 4 & Pemandangan yang indah. & 0.12 & 4.8 & 0.58 \\
\hline 5 & $\begin{array}{l}\text { Agrowisata yang terkenal } \\
\text { dengan ciri khasnya. }\end{array}$ & 0.10 & 4.7 & 0.47 \\
\hline & Jumlah Kekuatan & 0.52 & & 2.36 \\
\hline No & Kelemahan & Bobot & Rating & Skor \\
\hline 1 & $\begin{array}{l}\text { Perubahan iklim yang tidak } \\
\text { menentu. }\end{array}$ & 0.07 & 2.9 & 0.20 \\
\hline 2 & Kurangnya promosi. & 0.10 & 2.9 & 0.29 \\
\hline 3 & $\begin{array}{l}\text { Kurangnya kesadaran dalam } \\
\text { menjaga objek wisata. }\end{array}$ & 0.10 & 2.8 & 0.28 \\
\hline 4 & $\begin{array}{l}\text { Belum tersedianya toko } \\
\text { souvenir dan homestay. }\end{array}$ & 0.10 & 3.9 & 0.39 \\
\hline 5 & $\begin{array}{l}\text { Kurangnya sumber daya } \\
\text { manusia yang berpengalaman. }\end{array}$ & 0.11 & 3.5 & 0.39 \\
\hline & Jumlah Kelemahan & 0.48 & & 1.55 \\
\hline & Total Kekuatan dan Kelemahan & 1.00 & & 3.91 \\
\hline
\end{tabular}

Berdasarkan Tabel 4 menunjukan bahwa skor total hasil analisis internal adalah 3.91 yang menandakan kawasan agrowisata Rurukan berada pada posisi "sedang" dalam memanfaatkan kekuatan untuk menghadapi kelemahan yang dihadapi dalam pengembangan kawasan agrowisata Rurukan. Adapun yang menjadi kekuatan utama yang ada pada kawasan agrowisata Rurukan yaitu memiliki pemandagan yang indah dengan skor internal 0.58 , didukung dengan kawasan Rurukan yang memiliki tingkat kesuburan tanah yang baik yang mendukung pengembangan agrowisata dengan skor iternal 0.53. Kemudian yang menjadi kelemahan utama pada kawasan agrowisata Rurukan terletak pada belum tersedianya toko souvenir dan homestay dengan skor internal 0.39 dan kurangnya sumber daya manusia yang berpengalaman dengan skor internal 0.39 .

\section{Analisis Faktor Eksternal (EFAS)}

Analisis kondisi eksternal dilakukan terhadap faktor-faktor strategis yang terdiri atas peluang dan ancaman dalam pengembangan kawasan agrowisata Rurukan. Adapun faktorfaktor strategi eksternal yang dimaksud dapat dilihat pada Tabel 5.

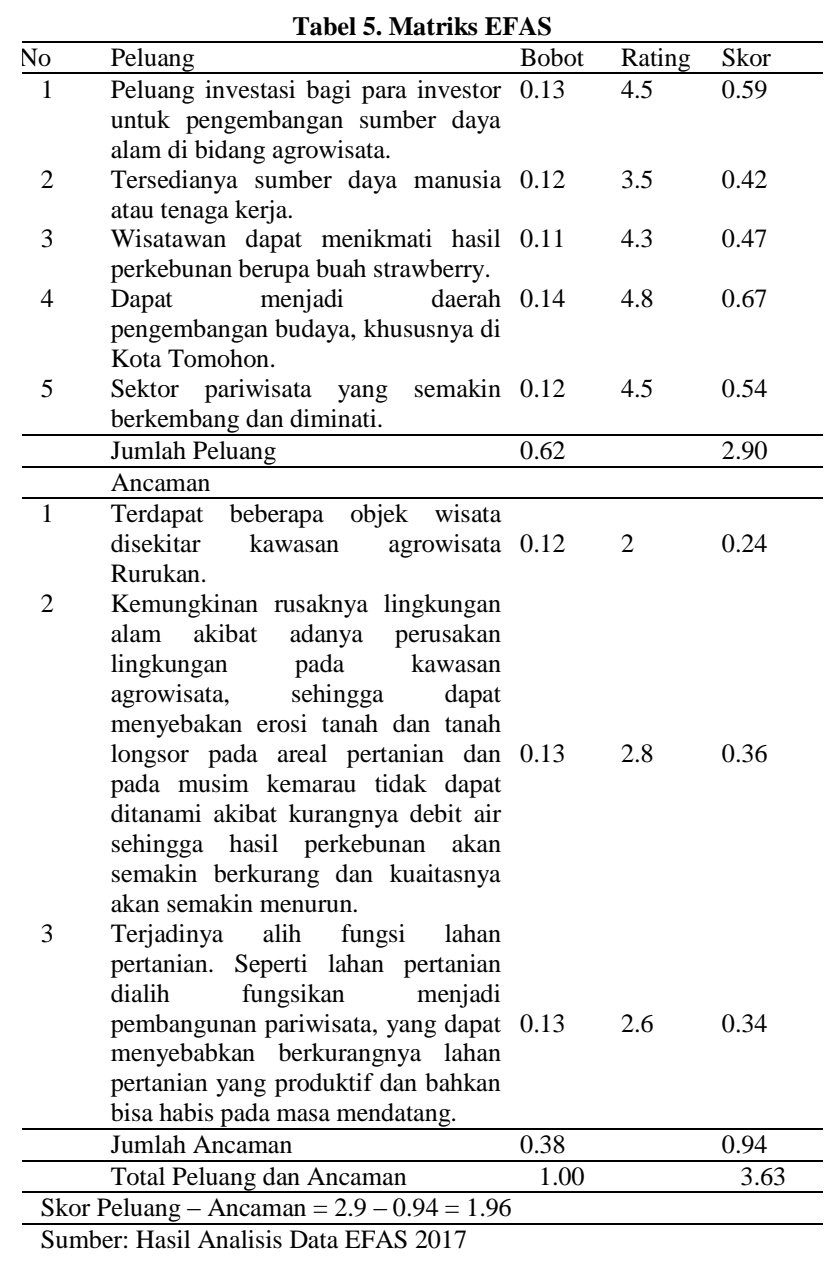

Hasil analisis faktor strategis eksternal melalu peluang dan ancaman mendapat skor total analisis eksternalnya adalah 3.63 yang menandakan bahwa pengembagan kawasan agrowisata Rurukan berada pada posisi ekternal yang "kuat" dalam memanfaatkan peluang untuk mengatasi ancaman yang dihadapi. Adapun peluang terbesar yang dimiliki dalam pengembangan kawasan agrowisata Rurukan adalah dapat menjadi darah pengembangan budaya, khususnya di Kota Tomohon dengan skor eksternal 0.67, dan didukung dengan 
adanya peluang investasi bagi para investor untuk pengembangan sumber daya alam dibidang agrowisata dengan skor eksternal 0.59. Kemudian yang menjadi ancaman utamanya adalah Kemungkinan rusaknya lingkungan alam akibat adanya perusakan lingkungan pada kawasan agrowisata, sehingga dapat menyebakan erosi tanah dan tanah longsor pada areal pertanian dan pada musim kemarau tidak dapat ditanami akibat kurangnya debit air sehingga hasil perkebunan akan semakin berkurang dan kualitasnya akan semakin menurun dengan skor eksternal 0.36, diikuti dengan terjadinya ahli fungsi lahan pertanian, seperti lahan pertanian yang dialihfungsikan menjadi pembangunan pariwisata, yang dapat menyebabkan berkurangnya lahan pertanian yang produktif dan bahkan bisa habis pada masa mendatang dengan skor eksternal 0.36.

\section{Pemetaan Posisi Agrowisata}

Menentukan posisi agrowisata dengan cara memadukan kekuatan, kelemahan, peluang, dan ancaman sehingga dapat ditentukan titik koordinat dan dipetakan pada matriks posisi.

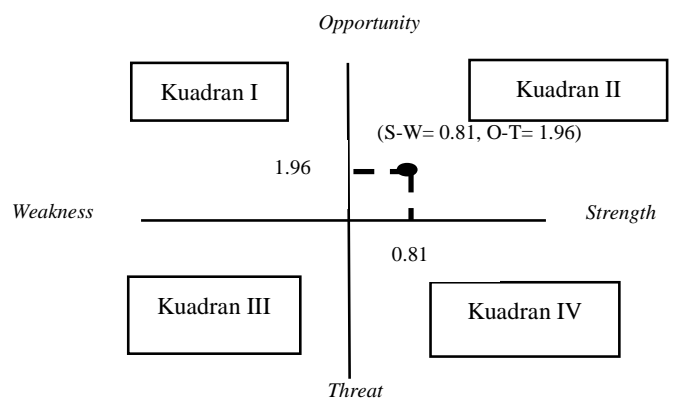

Gambar 1. Matriks Posisi Pengembangan Kawasan Agrowisata

Dari Gambar 1 menunjukan bahwa posisi relatif kawasan agrowisata Rurukan berada pada titik koordinat $(0.81,1.96)$ pada kuadran I yang menunjukan bahwa kawasan agrowisata Rurukan memiliki kekuatan dan peluang sehingga dapat memanfaatkan peluang yang ada dengan menggunakan kekuatan yang dimiliki. Strategi pengembangan yang sesuai dengan posisi kawasan agrowisata Rurukan adalah strategi progresif yang mendukung pada pertumbuhan agrowisata, dan berada pada Rapid growth strategy (strategi pertumbuhan cepat).

\section{Strategi Pengembangan Kawasan Agrowisata Rurukan}

Beberapa alternatif strategi dalam pengembangan kawasan agrowisata Rurukan, antara lain sebagai berikut :

\section{Strategi SO}

a. Memanfaatkan beberapa objek wisata yang sudah ada untuk menarik investor sehingga dapat menjadi sektor pariwisata yang semakin berkembang dan diminati di Kota Tomohon.

b. Memanfaatkan agrowisata yang terkenal dengan ciri khasnya untuk menjadi daerah pengembangan budaya, khususnya di Kota Tomohon.

c. Memanfaatkan tingkat kesuburan tanah yang baik di kawasan Rurukan untuk ditanami buah-buahan seperti strawberry untuk dinikmati oleh wisatawan.

\section{Strategi ST}

a. Menjaga ciri khas agrowisata dan melestarikan lingkungan sekitar untuk dapat bersaing dengan objek wisata lainnya.

b. Pelestarian lingkungan hidup agar tidak terjadi kerusakan lingkungan yang disebabkan dari penebangan hutan secara liar, dan alih fungsi lahan

3. Strategi WO

a. Mengundang para investor untuk meningkatkan sarana dan prasarana.

b. Meningkatan kesadaran masyarakat dalam menjaga objek wisata dan mendukung perkembangan agrowisata.

c. Memanfaatkan investor yang ada untuk pengadaan toko-toko souvenir dan homestay, serta memaksimalkan promosi untuk menarik wisatawan.

\section{Strategi WT}

a. Meningkatkan promosi dan fasilitas pendukung untuk mampu bersaing dengan objek wisata lainnya.

b. Meningkatkan kesadaran dalam menjaga objek wisata untuk meminimalkan terjadinya kerusakan lingkungan yang disebabkan dari penebangan hutan dan alih fungsi lahan.

Dari beberapa uraian di atas, menunjukkan bahwa kawasan agrowisata Rurukan berada pada posisi yang kuat dan 
berpeluang. Rekomendasi strategi yang diberikan adalah progresif, artinya kawasan agrowisata Rurukan dalam kondisi prima dan mantap sehingga dimungkinkan untuk terus melakukan ekspansi, memperbesar pertumbuhan dan meraih kemajuan secara maksimal. Maka rekomendasi strategi yang diberikan adalah Strategi S-O.

\section{KESIMPULAN DAN SARAN}

\section{Kesimpulan}

Berdasarkan hasil penelitian dan pembahasan, maka dapat disimpulkan bahwa strategi pengembangan kawasan agrowisata Rurukan adalah Strategi Pertumbuhan Cepat (Rapid growth strategy). Strategi pengembangan ini sesuai dengan posisi kawasan Rurukan yang membutuhkan strategi progesif untuk mendukung pertumbuhan, melalui beberapa strategi yang dapat diimplementasikan yaitu :

a. Memanfaatkan beberapa objek wisata yang sudah ada untuk menarik investor sehingga dapat menjadi sektor pariwisata yang semakin berkembang dan diminati di Kota Tomohon.

b. Memanfaatkan agrowisata yang terkenal dengan ciri khasnya untuk menjadi daerah pengembangan budaya, khususnya di Kota Tomohon.

c. Memanfaatkan tingkat kesuburan tanah yang baik di kawasan Rurukan untuk ditanami buah-buahan seperti strawberry untuk dinikmati oleh wisatawan.

\section{Saran}

Adapun hal-hal yang dapat disarankan berdasarkan hasil penelitian ini adalah berusaha untuk mempertahankan kawasan agrowisata Rurukan pada posisi yang kompetitif dalam pertumbuhan yang kuat untuk meningkatkan daya tarik kunjungan dan mampu bersaing dengan objek wisata lainnya yang berada disekitar kawasan agrowisata Rurukan. Kemudian masyarakat dan pemerintah harus lebih memperhatikan keadaan lingkungan di sekitar kawasan agrowisata Rurukan dengan meningkatkan kesadaran dalam menjaga objek wisata untuk meminimalkan terjadinya kerusakan lingkungan yang disebabkan dari penebangan hutan dan alih fungsi lahan. Misalnya Pemerintah dan Masyrakat berbondong-bondong untuk melakukan pengijauan ataupun penanaman pohon di daerah sekitar kawasan agrowisata Rurukan.

\section{DAFTAR PUSTAKA}

Ashar. M., 2015. Strategi Pengembangan Potensi Desa Bonto Lojong Sebagai Kawasan Journal.uin.alauddin.ac.id, diakses tanggal 2 oktober 2016.

BAPPENAS, 2004. Tata Cara Perencanaan Pengembangan Kawasan Untuk Percepatan Pembangunan Daerah. Direktorat Pengembangan Kawasan Khusus dan Tertinggal BAPPENAS.

Budiarti, S. d., 2013. Pengembangan Agrowisata Berbasis Masyarakat Pada Usahatani Terpadu Guna Meningkatkan Kesejahteraan Petani Dan Keberlanjutan Sistem Pertanian. Jurnal Ilmu Pertanian Indonesia, Vol 18, No 3. Journal.ipb.ac.id, diakses tanggal 14 Mei 2016.

Fahmi, I., 2014. Manajemen Strategi Teori dan Aplikasi. Bandung: Penerbit Alfabeta.

Mappigau, Palmarudi \& Esso, A. Sawe Ri. 2011. Analisis Strategi Pemasaran Telur pada Peternakan Ayam Ras Skala Besar di Kabupaten Sidrap. Jurnal. Fakultas Peternakan Universitas Hasanuddin.

Pamurladi, B., 2006. Pengembangan Agrowisata Berwawasan Lingkungan (Studi Kasus Desa Wisata Tingkir, Salatiga), Diss Program Pasca Sarjana UNDIP. eprints.undip.ac.id, diakses tanggal 29 September 2016.

Rangkuti, F. 2015. Analisis SWOT : Teknik Membedah Kasus Bisnis Cara Perhitungan Bobot, Rating, dan OCAI. Jakarta: Penebit PT.Gramedia Pustaka Utama. 
Sastrayuda, G. S., 2010. Hand Out Mata Kuliah Concept Resort and Leisure Strategi Pengembangan dan Pengolahan Resort and Liesure.

Setyowati, T., 2013. Pengembangan Agrowisata Sebagai Upaya Dalam Pemberdayaan Masyarakat Mangunan Kecamatan Dlingo Kabupaten Bantul. Skripsi UIN SUKA.

Siagian, S. P., 2004. Manajemen Stratejik. Jakarta: Penerbit PT. Bumi Aksara

Sujarweni, V.W., 2014. Metodologi Penelitan. Yogyakarta : Penerbit Pustaka Baru Press.
Tabuni, D,. Kapantow, G.H.M,. dan Rengkung, L.R., 2015. Strategi Pengemabangan Kawasan Wisata Danau Linow di Kota Tomohon Provinsi Sulawesi Utara. Jurnal ASE. Vol 11, No 3A. ejournal.unsrat.ac.id.

Tim Peneliti. 2015. Laporan Akhir Rencana Pengembangan Kawasan Agrowisata Rurukan. Dinas Pertanian Dan Peternakan Sulawesi Utara Bekerjasama dengan Fakultas Pertanian Universitas Sam Ratulangi: tidak dipublikasikan.

Tjiptono, F., 2014. Strategi Pemasaran. Yogyakarta: Penerbit CV ANDI. 